\title{
Effect of Internal and External Challenges on Micro and Small Enterprises' Prospect
}

\author{
Mr. Mikrie Fekadu (MBA) \\ College of Business and Economics, Dire Dawa University, P.O. Box 1362, Dire Dawa, Ethiopia
}

\begin{abstract}
The purpose of this study was to assess the effect of internal and external challenges on Micro and Small Enterprises' prospect in Debretabor town. The research type employed to conduct this study was descriptive survey method in 200 owners of MSEs in Debretabor town. As to the tools that the researchers used were questioner, focused group discussion and unstructured interview. These were involved in 34questionnaires that contain 4 questions on owner's information and 6 questions on external challenges, 20 questions on internal challenges and 4 questions about enterprises prospects. Regarding to the unstructured interview for Debretabor town MSEs Office and Debretabor Poly Technic College, 8 unstructured items were used. For focused group discussion 4 topics were administered.The result of the this study shows that prospects of SMEs can be negatively affected by Marketing problem followed by control and evaluation problem, environmental challenges and financial problems respectively in Debretabor town.Generally speaking, as the researcher has seen those back-ups from the study, there must be an immediate and strict measure should be taken by the local government and owners of MSE. Such as to solve the problem of finance, the government should develop specially loan system/strategy for SMEs with minimum collateral amount at fair interest rate. At the same time owners of MSEs should create a means of solving financial problems by forming informal financial sources association like "Equib" and through savings. MSEs should create an effort to compete with large companies by forming unions, and associations rather than competing independently and the local government also should encourage and improve the situation to MSEs owners to operate in different sectors to minimize the intensity of competition among themselves. And lastly owners should avoid unplanned withdrawal of cash for personal use and should apply principles of business entity concept.
\end{abstract}

Keywords: Challenge, prospect, micro and small enterprises

DOI: $10.7176 / \mathrm{EJBM} / 11-1-06$

\section{Introduction}

Operating in MSEs provides a freedom to operate independently, increasing personal savings by making profit and provides personal satisfaction as well as increases a countries economy. In most countries up to $99 \%$ of all business are small business and $40 \%$ of most countries' business employees are employed in small business (Manu etal., 2008)

In Ethiopia, MSE sector plays pivotal roles in bringing about economic transition through creating opportunities to use existing human and material resources; and through this contributing to poverty alleviation in the short term and poverty eradication in the long run. Particularly, the sector has crucial role in playing as a quick remedy for the increasing unemployment problems in the country. But it has not been able to contribute substantially as needed (Endalkachew,2008)

Micro and Small sized enterprises consists very heterogeneous groups. MSEs are found in a wide array of business activities, ranging from the single artisan producing agricultural implements for the village market, the coffee shop, the internet café Textile and garment, Leather crafts and shoe making, Wood and metal works, Construction, Food processing, Municipal Activities, Kiosk shops, "Gulet" and manufacture of furniture ( Habtamu, n.d)

This indicates that the sector is a potential area to solve unemployment problem and makes beneficiary specially poor societies like unemployed youth \& women, Universities and TVET school graduates, school drop outs, existing MSEs such as weavers, street vendors, traditional handicraft operators, people who live on the Street.

In Ethiopia MSEs is confronted with various problems, namely lack of capital, working premises, marketing problems, shortage of supply of raw materials and lack of qualified human resources are the most pressing problems facing MSEs (Ageba \& Ameha, 2004)

The problems that MSEs face in Amhara region are related to each other to the legal and regulatory environments, access to market, finance, business information, business premises, the acquisition of skills and managerial expertise, access to appropriate technology, access to infrastructure, and in some cases discriminatory regulator practices. Encouragement and promotion activities of MSEs in the region are week. Though the regional government is formulating the MSE regional strategy and put in place institution to implement the strategy, little is achieved so far but MSEs are still facing sever constraints in their activities and in their promotion and developments are, therefore, hampered (Waleligne \& Wendimu, 2002) 
Micro and small enterprises are an important source of job opportunity and income for many people in different countries, particularly in most developing countries. Hence in Ethiopia, a number of employment opportunities generated from this sector unemployment is still a major challenge. These have been forcing the Ethiopian government to give due attention and to incorporate issue of MSE in urban and rural development and poverty reduction policies and strategies. Then the FDRE has undertaken different measures starting promulgate of laws to establishment of executives starting from federal to grass root level to enhance the strength and competence of MSEs. However, the sector is till affected by varies challenges.

Many surveys are conducted on challenges of MSE. Some of these are a survey report on Ethiopian MSEs by Ageba \& Ameha (2004), Anthony \& Onugu in Nigeria (2005), Habtamu Tezera (n,d) at Addis Ababa in the Arada Sub City, Endalkachew Mulugeta (2008) at Addis Ababa in Addis Ketema Sub City, Waleligne \& Wendimu (2002) in ANRS, Ogutu \& Gakonyo (2006) in Tanzania .

All these researchers illustrates that the sector is highly affected by different challenges and those problems are multidimensional but relatively similar in nature. The common internal problems of MSEs are categorized under managerial, marketing, financial and environmental factors such as intensity of competition, bureaucracy in company registration \& licensing, unfair competition, lack of low cost and accessible training facilities, tax burden and poor infrastructure.

Waleligne \& Wendimu, (2002) also further investigated culture of the society influences on the development of MSEs. Culture is also considered as a challenge on research conducted in Nigeria by Anthony \& Onugu (2005), Endalkachew (2008) also revealed that wrong pricing, high rent charges are also internal problems that affect MSEs' prospects.

The purpose of this research is to investigate the extent of the above factors on the prospects of MSEs in Debretabor town regarding profitability, continuity and employment opportunity of MSEs and to fill gaps that are not identified by other researches regarding internal problems such as control and evaluation.

\section{Literature}

\subsection{Definition of Micro and Small Business}

Even if the legal definition of MSEs varies from country to country, According to the new Small \& Micro Enterprises Development Strategy of Ethiopia the working definition of MSEs is based on capital and labor as follows (Micro Enterprises Development Strategy of Ethiopia, 2011)

Table 2: Classifications of MSEs in Ethiopian Context

\begin{tabular}{|c|c|c|c|c|}
\hline $\mathrm{NO}$ & Enterprise level & Sector & Hired labour & Capital \\
\hline \multirow{2}{*}{1} & \multirow{2}{*}{ Micro } & Industry & $<5$ & $\begin{array}{l}\$ 6000.00 \text { or } £ 4500.00 \\
<\text { Birr } 100,000.00\end{array}$ \\
\hline & & Service & $<5$ & $\begin{array}{l}\$ 3000.00 \text { or } £ 2200.00 \text { or } \\
<\text { Birr } 50,000.00\end{array}$ \\
\hline \multirow[t]{2}{*}{2} & \multirow[t]{2}{*}{ Small } & Industry & $6-30$ & $\begin{array}{l}\$ 90,000.00 \text { or } £ 70,000.00 \\
<\text { Birr } 1,500,000.00\end{array}$ \\
\hline & & Service & $6-30$ & $<$ Birr 500,000.00 \\
\hline
\end{tabular}

Source: Micro Enterprises Development Strategy of Ethiopia (2011)

\subsection{An Overview of Institutional and Legal Framework for MSEs Development in Ethiopia}

Micro \& Small Enterprise Development Program in Ethiopia meaningfully has been given due attention by government since 2004/2005. Even though in 1977, the Handicraft and Small Scale Industries Development Agency (HASIDA) was establish to provide training mainly in management and technical skills and to serve as coordinating agency for Government policy on small enterprises. Shortage of funds and unfavorable Government policy toward the private sector in the 1980s made it extremely difficult for HASIDA to have an impact on the development of local small enterprises (Habtamu, n.d.)

Until 2004/2005, the national strategy was implemented by Federal MSEs Development Agency organized only at national level. Because of this, it was very difficult to make the strategy practical specially in delivering business development service for SME operators (Konjit,n.d.)

Thus, by considering the critical role of the sector and the constrained faced by SME operators since 2004/2005 the government of Ethiopia decide to establish MSEs coordinating body at regional level. Accordingly, MSEs development Agencies are decided to set up in all regions. Then ANRS based on the proclamation no 42/1999 has formulated a strategy for MSEs development in the region knowing the enormous importance that this sector can bring for the society of the region in such as creating employment opportunity, bring rapid economic growth, produce wide range of goods and services which are accessible and cheaper for huge number of persons of the region (Konjit, n.d.)

Currently the Ethiopian government amends MSEs strategy with the objective of that in addition that the 
sector play alleviating poverty \& reducing unemployment, to help out the sector to play its pivotal role as a base to medium and large scale industry. The strategy is implemented all over the country and in amending the strategy a lot of experiences had took from different countries especially from India, Japan and Malaysia (ibid)

\subsubsection{Government Supports and Selected Sectors}

In recognition of the enormous potential roles of MSEs, Ethiopia has been supporting MSEs through the investment incentives scheme, consisting of exemptions from income taxes and duties on imported capital goods, since the early 1990. The income tax exemption scheme applies to MSEs operating in specific industries (engineering firms) and located in government-preferred or underdeveloped locations (Emerta \& Brixiova, 2010)

Various special measures and programmes have been designed and policies articulated and executed by the government to encourage MSEs development and hence make them more vibrant, but since our country has limited capital, government support to MSEs depending up on the importance of the sector in the economy. Accordingly the FeMSED A selected growth oriented sectors for maximum government support and the rest non selected sectors will get minimum support (Micro enterprises development strategy of Ethiopia, 2011)

Some of growth oriented sectors are: In the manufacturing sector: Metal \& engineering, textile and garment, leather products, wood work products, agro processing and handicraft products. In the construction sector: contractor, building material production, cobble stone production, traditional way of mining extraction. In urban agriculture: cattle fattening, honey production, forestry, poultry farm, animal food preparation. In trade sector: domestic product whole sale and retail trade and in service sector: solid waste collection and recycling, maintenance service, etc. For these sectors the government supports by giving work premises, counseling service, loan provision, by accessing technology (Micro Enterprises Development Strategy of Ethiopia, 2011)

According the FeMSEDA types of Government Support for MSEs for growth oriented sector are working premises with least leasing price, product display centre with least leasing price, technical and business management training, counseling service, loan provision, market linkage particularly with government development programs (e g. Housing development,) exhibition, trade fair organization and access to technology (Ibid)

\subsection{Challenges of MSEs}

Many small firms suffer significant shrinkage at certain points in their lives, with negative implications for the job security of their employees. Some of the factors that suffer MSEs are: financial limitations, staffing problem, higher direct costs, lack of acceptance. (George etal., 2008) As far as the causes of sickness in small scale industry are concerned, it cannot be attributed to a single factor. In fact, it is an overcome of the cumulative effect of many factors/causes working simultaneously which may not be closely inter-related on even interdependent (Lall \& Sahai 2006)

MSEs fail because of the following challenges; lack of managerial experience, disasters, inadequate record, expansion beyond resources, lack of information about customers, lack of marketing research, nepotism, lack of technical competence and absentee management (Hailay, 2007)

Most Ethiopian MSEs have not been able to contribute substantially as needed to the economic development particularly because of financial, product, and marketing problems. These problems are still major handicaps to their development. Lack of adequate finance and credit has always been major problem of Ethiopian small business. Small scale units do not have easy access to the capital market because they mostly organized on proprietary partnership bases and are of very small size. They do not have access to industrial sources of finance partly because of their size and partly because of the fact that their surpluses which can be utilized to replay loans are negligible. Because of their size and partly because of the fat limited profit they search for funds for investment purpose. Consequently, the approach moneylenders who charge high rate of interest hence small enterprises continue to be financially weak (Ibid)

The reasons why Nigerian MSEs are performing below standard are One is 'internal' and relates to attitudes, habits and way of thinking and doing things while the other relates to environment including educational system, culture, government, lackluster approach to policy enunciation and poor implementation, low-level capacity in management, marketing and technical know-how as well as low level knowledge of legal and regulatory practices, policies and accounting practices. The SME sector in Nigeria is replete with a multitude of problems some of which are intrinsic to it while others such as the lack of an enabling environment in terms of poor or non-existent infrastructure like bad roads, water, power, and access to finance are largely external. Other major problems which have contributed to the poor performance of MSEs include: limited access to long-term capital, high cost of even short-term financing, poor partnership spirit, dearth of requisite managerial skills and capacity, illegal levies, street urchins' harassments, over-dependence on imported raw materials and spare parts, poor inter and intra-pectoral linkages that make it difficult for the MSEs to enjoy economies of scale production, bureaucratic bottlenecks and inefficiency in the administration of incentives that discourage rather than promote SME growth, weak demand for products arising from low and dwindling consumer purchasing power, incidence of multiplicity of regulatory agencies and taxes that have always resulted in high cost of doing business and poor 
corporate governance and low entrepreneurial skills arising from inadequate educational and technical background for many SME promoters (Anthony \& Onugu)

Problems of MSEs are grouped into five areas based on a pre-specified scheme (1) human relations, (2) accounting finance; (3) marketing; (4) internal management, and (5) external management. Although they have generally concluded that the most prevalent areas in which SME have problems are sales/marketing, human resource management, and general management, they specifically reported promotion, marketing research and training as the most frequently encountered problems (M. Welsh, 1988)

\subsubsection{External Challenges}

The external environments are beyond the control of the industry and usually affect the industry group as a whole and include none availability of raw material (or irregular supply, or availability at a high price), a general recessionary trend in the economy which affects the overall performance of the industrial units, high cost of production facing a low realization of sales revenue, irregular supply of vital inputs such as power, water, transportation, unfavorable change in government/institutional polices, industrial strikes, unrest and natural climates such as drought, earthquakes, flood etc (Lall \& Sahai 2006)

External Environment has two-layers- the task and general environment. The task environment involves environmental elements that are commonly defined to include competitors, suppliers, customers and technological factors. The general environment refers to sectors that affect organizations indirectly and include economic, political, demographic, cultural, regulatory and social sectors. These sectors are expected to influence the performance of small firms because they differ in uncertainty. Thus, it is critical that small firms be aware of the nature of the environment that they currently face and anticipate facing, and the need to incorporate changes in their strategy formulation and implementation (Habtamu, n.d.)

Challenges are multi-dimensional. As trade barriers, transport and communication costs fall, MSEs are required to add more value to their products to stay ahead and compete with lower cost rivals. Consumer demand is changing rapidly as incomes rise and choices increase when imported products become easily available in domestic markets. Technological advances create new products and transform almost every stage of business from production to marketing, sourcing and logistics (Promoting Entrepreneur ship and Innovative MSEs in a Global Economy: Towards a More Reasonable and Inclusive Globalization, 2004)

\subsubsection{Internal Challenges}

Internal problems are within the control of the industry. It may be an income of some internal deficiencies or shortcomings in its various functional areas such as marketing, management production, finance, etc. Most of the causes of industrial sicknesses are, however, due to internal factors such as lack of control on key areas like management, finance, marketing, inventory, shortage of working capital, an improper demand forecasts for the products to be sold, inappropriate choice of technology, non-flexibility of fixed assets, wrong location or layout of industry. These problems need immediate managerial actions and include human resources management, business planning, organizing, and directing (ibid)

Internal problems are "lack of ...", "missing...", or weak points such as no control over raw materials, limited product life, poor design of product, weak selling effort, comparatively high price, no technical expertise of owners, lack of promotion experience, technological obsolescence, inexperienced managers/owners, lack of working capital and low level of stocks in times of peak sales (CEFE International, 1998)

The major reason that business fail is incompetence. The owners simply do not know haw to run the enterprise. They make major mistakes an experienced. The second most common reason business fails is unbalanced experience. This means owners do not have a well-rounded experiencing the major civilities of the business, such as finance, purchasing, selling and production. Because the owner lacks experience in one or more of these critical areas, the enterprise gradually fails. A third common cause, of business failure is lack of managerial experience. The owners simply do not how to manage people. The forth common reason is lack of experience in the line that is the owner has entered a business field in which he or she has very little knowledge (Hailay, 2007)

\subsection{Prospects of MSEs in Ethiopia}

It is fair and proper to recognize the fact that the government of Ethiopia did not fold its arms to watch the MSEs stagger in the extent of problems. The government appreciates the opportunities MSEs create for employment, their contributions to economic growth and development as well as the constraints and difficulties in their operating environment (Mulu, 2009)

In Ethiopia, the numbers of MSEs increased from time to time. The increase has resulted from the extensive growth of the number of graduates from universities and technical and vocational Colleges. Because of this and recognizing their importance for economic development, in recent years the Ethiopian government has begun to address the problems that impede the growth by putting several programmes and policies that would provide an empowering operating environment. These support programmes and policies include technical services for innovation, financial services, training and investment promotion (Endalkachew, 2008) 
The Ethiopian government recognizes the significance of this sector and shows its dedication to promote the MSEs development by the issuance of national micro and small enterprises strategy in 1997 and the Establishment of the Federal Micro and Small Enterprises Development Agency. Ethiopia's industrial development strategy issued in 2003 also singled out the promotion of MSEs development as one of the important instruments to create productive and dynamic private sector. The promotion of this sector is justified on the grounds that enhancing growth with equity, creating long-term jobs, providing the basis for medium and large enterprise and promoting exports etc. The strategy puts a means to support the MSEs such as, infrastructure, financial facilities, supply of raw materials, and training (Ageba \& Ameha, 2004)

The promotion of MSEs is becoming a popular development tool. Accordingly, governments and donors in the developing countries have shown increasing interest in promoting innovations and entrepreneurship. They have initiated various support programmes with the aim to improve MSEs' competitiveness through enhancing technology and innovation capabilities such as upgrading product quality, improving design and packaging, and training to improve competitiveness. (Mulu, 2009)

The vision of this MSEs development strategy is based on the country's overall development strategy that is Plan for Accelerated and Sustainable Development (PASDEP) and the adoption of the market economic system. Thus the government of Ethiopia developed a strategy frame work to create an enabling environment for MSEs by setting the following specific objectives.

1. Facilitate economic growth and bring about equitable development

2. Create long-term jobs

3. Strengthen cooperation between MSEs

4. Provide the basis for the Medium and Large Scale Enterprises

5. Balance preferential treatment between MSEs and bigger enterprises

6. Promote export (Micro enterprises development strategy of Ethiopia, 2011)

\subsection{Empirical Findings}

A research conducted in Tanzania by Francis \& Gakonyo, (2006) shows that MSEs in Tanzania are not competitive enough in terms of prices of their products due to high production costs, harm SME competitiveness, poor infrastructure and inadequate capital, high transaction costs and limited capacity to produce and deliver in a sustainable and timely manner.

A research conducted in Kenya by Audretsch \& Lehmann (2009) shows that in Kenya, lack of planning, improper financing and poor management have been posited as the main causes of failure of small enterprises.

Anthony \& Onugu, (2005) in Nigeria conducted a study shows that the top ten problem areas of MSEs in Nigeria in decreasing order of intensity include: management, access to finance, infrastructure, government policy inconsistencies and bureaucracy, environmental factors, multiple taxes and levies, access to modern technology, unfair competition, marketing problems and non-availability of raw materials locally. Thus managerial problems represent the greatest problem facing MSEs in Nigeria.

A research conducted by Mohammed, (n.d) in Nigeria also, the Nigerian MSEs are affected by three categories factors: external environment which consists, marketing, technology and information access; entrepreneurial readiness, which consists of social network, legality, capital access, government support , business plan; and characteristics of entrepreneur which consists of , age, gender, work experience education characteristics of enterprise, origin of enterprise, length time in operation, size of enterprise, capital source and location.

Also another research conducted in Nigeria by M. Chu et al., (2008) Nigerian small enterprises faces weak economy, unsafe location, undependable electricity supply and a lack of management training.

A research conducted by Lahiri (n.d.) In India MSEs face a tough situation due to extreme competition from large industries due to withdrawal of subsidy, lack of infrastructure, antidumping policy, challenges on product standardization, total quality management etc.

Endalkachew (2008) in Addis Ababa, in the sub city of Addis Ketema conducted a study, his finding shows that the constraints facing MSEs in most developing economies are relatively similar: unfavorable legal and regulatory environment and, in some cases, discriminatory regulatory practices; lack of access to markets, finance, business information; lack of business premises at affordable rent; low ability to acquire skills and managerial expertise; low access to appropriate technology; and poor access to quality business infrastructure.

A survey conducted in Addis Ababa at Arada sub city by Habtamu (n.d.) shows that the challenges that faces MSEs are: Environmental factors such as: intensity of competition, availability/affordability of business license, rapid and costly technological changes, climate conditions and bureaucracy in company registration $\&$ licensing are their major problems. Internal problems such as: human resource development and managerial problems, financial problems, marketing related problems such as product marketing demand and supply forecasting and knowledge of market have greater impact on their business than any other factor. Other factorslike lack of business development services, poor waste disposal system and tax burden challenge the 
performances of MSEs sector

A survey conducted in Amhara region by Waleligne \& Wondimu (2002) shows that, MSEs found in Amhara region faces with several challenges. These challenging factors are: Lack of focus on providing basic marketing techniques and lack of practical assistance in marketing the products of the operators, formal financial institutions are reluctant to avail credit facilities to MSEs, lack knowledge about available financing programs, most MSE operators are unclear regarding rules and regulations and the government criteria for license and registration are so strict, lack awareness about the already existing training facilities and, the constructed commercial premises are not sufficient and the existing land acquisition procedures do not consider accessibility of land for MSEs operators, cultural influence and lack of infrastructural facilities are major challenges.

A research conducted by Philip (2010) in Bangladesh shows that, external environment such as: social network, government support, and legality and management know-how, product and services are the most significant determinants of business success of MSEs

A research conducted by Chittithaworn etal.,(2010) in Thailand shows that, external environment factor such as: social network, government support, and legality, are the key strategic dimension in external environment of business survival. Customer and market and resources and innovative product, quality, cost, reliability, and services are the key strategic dimension in business continuity as well as profitability

Moorthy etal., (2012) in Malaysia the performance of MSEs are determined by: effective entrepreneurship, appropriate human resources management, use of marketing information, and application of information technology are significant related to the performance of the companies

\subsection{Conceptual Framework}

MSEs have their own objective of success, but the sector is affected by various challenges to achieve their vision and these challenges are grouped into five areas (1) External factors are beyond the control of the industry and usually affect the industry group, social network, government support, and legality Philip (2010) Intensity of competition, poor infrastructure, bureaucracy in company registration and licensing, the impact of local small market and population size in the area culture, values and norms and tax burden. Habtamu (n.d.) (2)financial problems ; consists availability of business loans, availability of equity capital for business, availability of personal loans for business, high cost of borrowing, high operating expenses, lack of money, personal guarantees for business loans, and poor cash flowAuken \& Carter (2006) Iinadequate capital, high transaction costs Anthony \& Negwu (2006) Lack of record keeping and documentation Poor management of cash, high investment in fixed assets during start-up, unplanned withdrawal of cash for personal use. Abdullah and Baker (2000) (3) Marketing problems consists of; technology and information access and lack of demand forecast Alkali etal., (n.d) (4) Management problems includes, lack of experienced employees in the, market, dependence on family and relatives for labor, personal problems (health, social etc) of owner/manager, lack of experience in owning/running a business, lack of vision and growth orientation, lack of competitive benchmarking, lack of evaluating results against plans on continuous basis, lack of general managerial experience skills and training and lack of strategic business planning. Drucker (1982) (5) control and evaluation problems. Over emphasis on short term profitability, lack of quality control system, inability to compete with large companies and fear of failure, bankruptcy and risk taking (Habtamu, n.d.)

\section{Figure1:The Framework of Relationship between Independent Variable and Dependent Variable Independent Variable Dependent Variable}

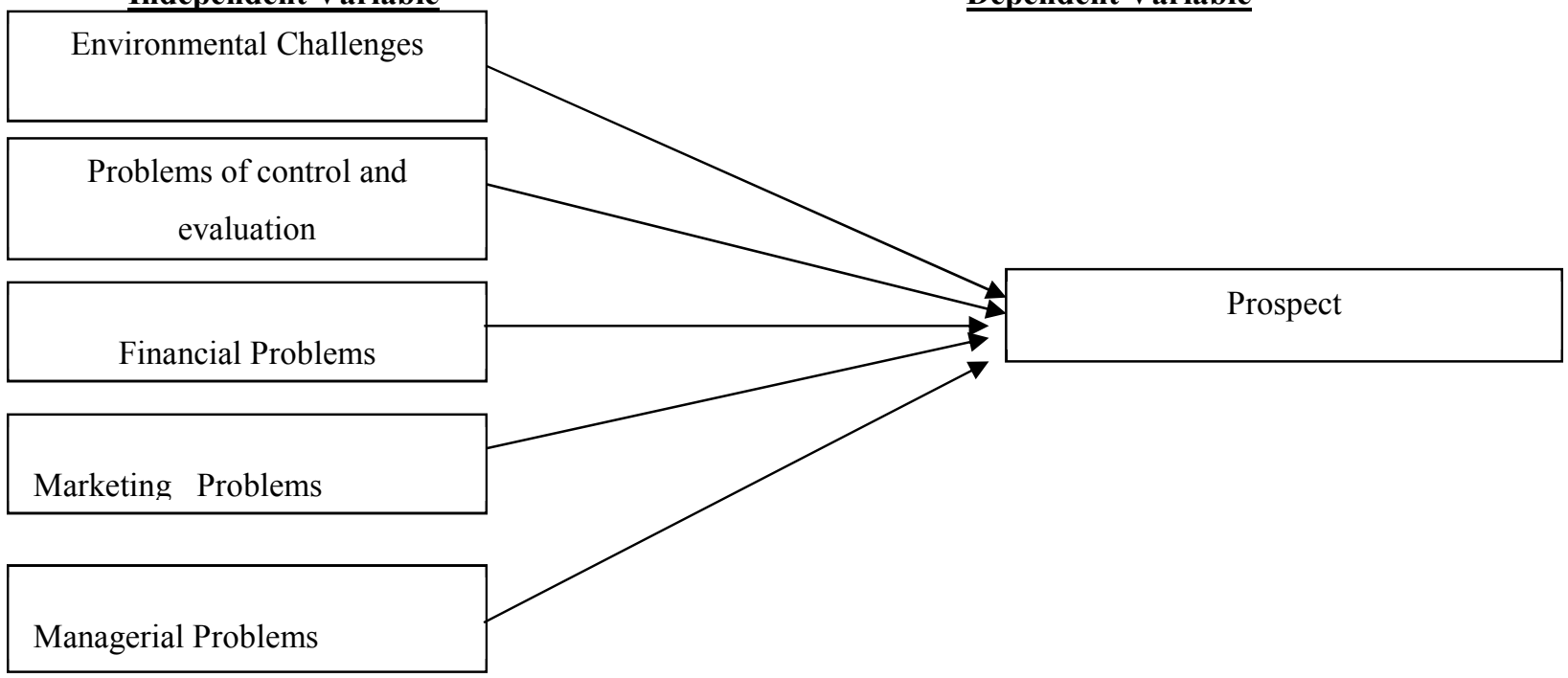




\section{Methodology of the study}

\subsection{Design of the Study}

The study is conducted on assessing the effect of internal and external challenges on the prospects of MSEs in Amhara region particularly in Debretabor town. As the researcher's information there was no research conducted before on the issue in the town and due to accessibility to information, the district is selected purposely. The method of survey used for the study is descriptive. This method is believed to be convenient to discover the challenges and prospects of MSEs.

\subsection{Population and Sample size}

The total number of enterprises legally registered and participating in this district is 519 . This had been taken as the overall population of the study. The sources of information for the study were owners of MSEs, MSEs town administrative officers and Debretabor Poly technic college.

The researcher used stratified random sampling method and the strata's are the sectors i.e.Manufacturing, Construction, Business, Service and Urban agriculture. From each stratum the sample were selected through random sampling technique.This technique avoids personal bias and all elements of the population to have equal chance of being selected. To determine the sample size the researcher used a formula of Kreijcie \& Morgan (1970) cited by (Amin, 2005)

$$
\mathrm{n}=\quad \frac{N}{1+(N)(e)^{2}}
$$

Where

$N=$ is the total population

$n=i$ s the sample from the population

$e=$ is the error term, which is $5 \%$ (i.e. at $95 \%$ confidence interval)

$$
\mathrm{n}=\frac{519}{1+(519)(.05)^{2}}=226
$$

\begin{tabular}{|c|c|c|}
\hline Sector & Number & Size in $43.5 \%$ \\
\hline $\begin{array}{l}\text { 1. Manufacturing Sector } \\
\text { - Tailor } \\
\text { - Leather and leather products and others } \\
\text { - Food processing and beverage } \\
\text { - Metal works and engineering } \\
\text { - Wood work and furniture } \\
\text { - Traditional hand craft }\end{array}$ & $\begin{array}{c}14 \\
4 \\
43 \\
25 \\
27 \\
10\end{array}$ & $\begin{array}{c}7 \\
2 \\
19 \\
11 \\
12 \\
4\end{array}$ \\
\hline $\begin{array}{l}\text { 2. Construction Sector } \\
\text { - Contractor } \\
\text { - Subcontractor } \\
\text { - Construction materials production } \\
\text { - Lapidary } \\
\text { - Coble stone }\end{array}$ & $\begin{array}{c}3 \\
8 \\
29 \\
1 \\
41\end{array}$ & $\begin{array}{c}1 \\
3 \\
13 \\
0 \\
18\end{array}$ \\
\hline $\begin{array}{ll}\text { 3. } & \text { Business Sector } \\
\text { - Retail, Container shops and others } \\
\end{array}$ & 162 & 70 \\
\hline $\begin{array}{l}\text { 4. Service sector } \\
\text { - Cafe and restaurant } \\
\text { - Hygiene service, solid waste collection, recycling and guard } \\
\text { - Electronics and electrical system maintenance } \\
\text { - Beauty salon and barber } \\
\text { - Photocopy and printing } \\
\text { - Other services }\end{array}$ & $\begin{array}{l}75 \\
5 \\
15 \\
14 \\
12 \\
11\end{array}$ & $\begin{array}{l}33 \\
2 \\
7 \\
6 \\
5 \\
5\end{array}$ \\
\hline $\begin{array}{l}\text { 5. Urban Agriculture sector } \\
\text { - } \quad \text { cattle fattening } \\
\text { - Gabion box } \\
\text { - } \quad \text { poultry farm } \\
\text { - Modern forestry } \\
\text { - } \text { Milk and milk products }\end{array}$ & $\begin{array}{l}3^{6} \\
2 \\
7 \\
2\end{array}$ & $\begin{array}{l}2 \\
1 \\
1 \\
3 \\
1\end{array}$ \\
\hline Total & 519 & 226 \\
\hline
\end{tabular}

Therefore, 226 MSEs from 519 had taken as a sample as follows.

Table3: Total population and sample size by strata 


\subsection{Data Collection Instruments}

The researcher used three types of primary sources i.e. Questionnaire, interview and focused group discussion. The data was mainly obtained from owners of MSEs, Debretabor town MSEs Office and Debretabor Poly Technic College.

\subsubsection{Questionnaires}

The first section contains four questions about general information of owners and enterprises. In the second section the respondents were asked to rank statements on contextual condition related to each challenging factor faced by the MSEs. A total of 30 questions were adapted and rregarding the data interpretations for variables used; measurement was used on the basis of the survey; $5=$ strongly agree; $4=$ agree; $3=$ disagree; $2=$ strongly disagree; $1=$ I don't know.

External challenges a total of six questions were developed to measure the extent of external challenging factors on the prospects of MSEs using 5-point liker scale anchored by strongly agree to strongly disagree. This part is adapted from Habtamu (n.d) who conducted a research at Addis Ababa, Arada sub city on challenges and opportunities of SMEs

Internal challenges This part consisted of 20 questions which were intended to measure the extent of internal challenges and categorized into four categories such as financial problem, marketing problem, management problem and control and evaluation andthese parts are also adapted from Habtamu Tezera (n.d).

Prospects of enterprises this section contains four questions about enterprises continuity, profitability and creating job opportunity in using5-point liker scale anchored by strongly agree to strongly disagree.

To assure the actual representation and validity of the sample, each sample was taken proportionally from each stratum through simple random sampling method.

Before the actual data gathering, the pilot test was conducted and Pre-test questionnaires given to 26 owners of MSEs. But to avoid bias these owners of MSEs were not parts of the study. Depending on feedback, some items were improved, redundant and unnecessary questions rejected and appropriate questionnaire for final data collection prepared. After the pilot test had been completed, the validity of the scales utilized in this study was assessed for content validity and the reliability of the scales was examined by computing their coefficient alpha (Crombach's Alpha) for five independent variables and the dependent variable were above .70. Therefore data that were collected for this research were considered to be consistent.

Table 4: Results of Reliability Test: Cronbach's Alpha

\begin{tabular}{|r|l|l|c|c|}
\hline \multicolumn{2}{|c|}{ Variables } & \multicolumn{1}{|c|}{ Construct } & Chronbach's Alpha & Number of items \\
\hline & Dependent Variable & Prospects of MSEs & $\mathbf{. 7 0 9}$ & $\mathbf{4}$ \\
\hline \multirow{5}{*}{ External } & Independent variable 1 & Environmental challenges & $\mathbf{. 7 0 6}$ & $\mathbf{6}$ \\
& Independent variable 2 & Managerial Problems & $\mathbf{. 7 1 1}$ & $\mathbf{5}$ \\
\cline { 2 - 6 } & Independent variable 3 & Marketing Problems & $\mathbf{. 7 0 8}$ & $\mathbf{5}$ \\
\cline { 2 - 5 } & Independent variable 4 & Control and evaluation problems & $\mathbf{. 8 0 1}$ & $\mathbf{5}$ \\
\cline { 2 - 5 } & Independent variable 5 & Financial Problems & $\mathbf{. 7 0 1}$ & $\mathbf{5}$ \\
\hline
\end{tabular}

Source: Developed for the Research, 2013

To re-examine the adapted instrument the researcher tested content validity. Validity refers the extent to which data accurately reflects what they meant to reflect. Content and construct validity are the most sophisticated and rigorous types of validity and the most recommended types of validity for social studies Koigi (2011). The content validity was check by factor analysis in the following manner.

The content validity of the study is assessed using factor analysis through KMO (Kaiser-Meyer-Olkin) and Bartlett's test of the SPSS output. According to Field (2005), KMO value indicates the sampling adequacy of the study and KOM value should be above the bare minimum of $\mathbf{. 5 0}$ for all variables. The Bartlett's test also indicates the test of Sphericity and significance level of the measurement instrument at $\mathbf{p}<. \mathbf{0 5}$. Thus, the KMO and Bartlett's test result of this study shown blow.

As shown in Table 5, the KMO value of all variable is equal or above the proposed cut-off level KMO $>.5$ (i.e. for External Challenges $=.600$, Managerial problems $=.500$, Marketing problems $=.678$, Control and evaluation problem $=.598$, Financial problem $=.883$, and for prospects $=.711$ ); and the Bartlett's test of all variable of the study are highly significant at $\mathrm{P}<.002$. Therefore, it is considered as sample of the study is suitable and illustrative. 
Table 5: KMO and Bartlett's test

\begin{tabular}{|c|l|c|c|c|c|}
\hline № & \multicolumn{1}{|c|}{ Variables of the study } & $\begin{array}{c}\text { KMO- measure of } \\
\text { sampling Adequacy }\end{array}$ & $\begin{array}{c}\text { Approx. Chi- } \\
\text { square }\end{array}$ & $\begin{array}{c}\text { Degree of } \\
\text { freedom }\end{array}$ & Significance \\
\hline 1 & External Challenges & .600 & 38.24 & 2 & 0.000 \\
\hline 2 & Managerial problems & .500 & 24.33 & 2 & 0.000 \\
\hline 3 & Marketing problems & .678 & 110.30 & 15 & 0.000 \\
\hline 4 & $\begin{array}{l}\text { Control and evaluation } \\
\text { problem }\end{array}$ & .598 & 76.47 & 26 & 0.001 \\
\hline 5 & Financial problem & .883 & 18.43 & 6 & 0.002 \\
\hline 6 & Prospects & .711 & 138.60 & 20 & 0.000 \\
\hline
\end{tabular}

Source: Developed for the research, 2013

\subsubsection{Interview}

To supplement the information obtained through questionnaire, the researcher used unstructured interview with Debretabor MSEs officers and with Debretabor Poly Technic College Dean as a data gathering instrument. The questions are adapted from a research conducted at Addis Ababa in Arada sub city on Underlining Causes of Micro and Small Business Failures by EndalkachewMulugeta (2008)

\subsubsection{Focused Group Discussion}

To supplement the information obtained through questionnaire and interview and to avoid one side information only form the government body, focused group discussion was used with selected owners of MSEs. The discussion result was triangulated with the information obtained from questionnaires and interview. Questions for focused group discussion were totally prepared by the researcher himself and it was led by the researcher. In addition to this the researcher used secondary document sources from Debretabor poly Technic College and Debretabor MSEs office was used.

\section{a. Analysis of Data}

The collected data had been encoded and analyzed by using Statistical Package for Social Science (SPSS) computer software program version 16.0. And the following statistical methods were used for analyzing the data: Percentage analysis and Regression analysis was used to determine statistical relationship between dependent variables and independent variable and to examine the effect of internal and external challenges on the prospects of MSEs. Information obtained from interview and focus group discussion had been analyzed qualitatively.

4. Data Analysis and Data Discussion

Table 6: Demographic Characters of Owners of MSEs

\begin{tabular}{|l|c|c|}
\hline \multicolumn{1}{|c|}{ Category } & Number & \% \\
\hline Gender & & $\mathbf{5 3}$ \\
Male & $\mathbf{1 0 6}$ & $\mathbf{4 7}$ \\
Female & $\mathbf{9 4}$ & $\mathbf{8}$ \\
\hline Educational level & $\mathbf{1 6}$ & $\mathbf{1 1 . 5}$ \\
Below elementary school & $\mathbf{2 3}$ & $\mathbf{4 0}$ \\
Elementary school completed & $\mathbf{8 0}$ & $\mathbf{3 0}$ \\
Secondary school graduate & $\mathbf{6 0}$ & $\mathbf{1 0}$ \\
College certificate \& diploma & $\mathbf{2 0}$ & $\mathbf{2 5}$ \\
Bachelor degree & & $\mathbf{3 1}$ \\
\hline Length of Time with Organization & $\mathbf{5 0}$ & $\mathbf{2 4}$ \\
Less than one year & $\mathbf{6 2}$ & $\mathbf{1 5}$ \\
1-2 years & $\mathbf{4 8}$ & $\mathbf{5}$ \\
3-5 years & $\mathbf{3 0}$ & $\mathbf{2 4 . 5}$ \\
6-10 years & $\mathbf{1 0}$ & $\mathbf{1 5 . 5}$ \\
10 years above & & $\mathbf{3 2}$ \\
\hline Type of business sector you operate & $\mathbf{4 9}$ & $\mathbf{2 5 . 5}$ \\
Manufacturing & $\mathbf{3 1}$ & $\mathbf{2 . 5}$ \\
Construction & $\mathbf{6 4}$ & $\mathbf{1 0 0}$ \\
\hline Business & $\mathbf{5 1}$ & $\mathbf{5}$ \\
Service & $\mathbf{2 0 0}$ & \\
Urban agriculture & & \\
\hline Total respondents & & \\
\hline
\end{tabular}

Source: Developed for the research, 2013 


\subsection{Regression Analysis}

To assess the extent of impact of internal and external challenges on the prospects of MSEs, simple regression analysis was carried out. The result of a table of regression analysis in Table 14 indicated that $\mathrm{R}=.751, \mathrm{R}-$ square $=.564$ and adjusted $\mathrm{R}$ square is .553 . From this result the extent of internal and external challenges on the prospects of MSEs is clarified by the value of the R square. This means that $56.4 \%$ of the variation can be explained by the five independent variables such as environmental challenges, marketing problems, managerial problems, financial problems, and control and evaluation problems on the prospects of MSEs in this research.

Table 14: Model Summary of regression analysis

\begin{tabular}{|c|c|c|c|c|}
\hline Model & $\mathrm{R}$ & R Square & Adjusted R Square & Std. Error of the Estimate \\
\hline $\mathbf{1}$ & $\mathbf{. 7 5 1}^{\mathrm{a}}$ & $\mathbf{. 5 6 4}$ & $\mathbf{. 5 5 3}$ & $\mathbf{2 . 6 1 6}$ \\
\hline
\end{tabular}

Predictors: (Constant), management problem, control and evaluation problem, financial problem, marketing problem and environmental challenges.

\subsection{Regression Analysis of Internal and External Challenges on MSEs' Prospect}

Micro and Small businesses are faced with a number of challenges that affects their prospects. These challenges are diverse in nature and vary in intensity. The challenges among which are: environmental, control and evaluation factors, managerial, financial and marketing factors.

As shown in Table 15, the predictors which have highest beta value (.373) and respective t-value of 2.584 is marketing problem with .010 level of significance is the most determinant factor that challenge prospects of MSEs. Control and evaluation with beta of .344 and respective t-value2.977with .003 level of significance is the second determinant factors to challenge the prospects of MSEs. Environmental challenges with beta of .099 and respective t-value .801 with .040 level of significance is the third determinant factor that hinder the prospects of MSEs, financial problems with a beta of .094 and respective t-value 2.257 with .010 significance level is the fourth determinant factors that challenges the success of MSEs prospect and lastly poor management with beta of -.270 and respective t-value -3.598 with .000 is the last determinant factor to challenge the achievements of MSEs prospect.

This shows that the prospects of MSEs can be more affected by marketing problem followed by control and evaluation problem, environmental challenges and financial problems. Poor management has less significant effect on the prospects of MSEs' to achieve their vision in facilitating economic growth and bringing about equitable development, create long term jobs, provide the bases for the medium and large size scale enterprises and promote export.

Table 15: Results of Regression Analysis of Internal and External Challenges on the Prospects of MSEs

\begin{tabular}{|c|c|c|c|c|c|}
\hline \multirow[t]{2}{*}{ Model } & \multicolumn{2}{|c|}{ Unstandardized Coefficients } & \multirow{2}{*}{$\frac{\begin{array}{c}\text { Standardized } \\
\text { Coefficients }\end{array}}{\text { Beta }}$} & \multirow[b]{2}{*}{$\mathrm{t}$} & \multirow[b]{2}{*}{ Sig. } \\
\hline & B & Std. Error & & & \\
\hline (Constant) & 12.651 & 3.405 & & 3.715 & .000 \\
\hline Environmental Challenges & .100 & .125 & .099 & .801 & .040 \\
\hline Marketing problems & .395 & .153 & .373 & $\mathbf{2 . 5 8 4}$ & .010 \\
\hline Financial problems & .141 & .185 & .094 & 2.257 & .010 \\
\hline $\begin{array}{l}\text { Control and evaluation } \\
\text { problem }\end{array}$ & .682 & .229 & .344 & 2.977 & .003 \\
\hline Poor Management & -.441 & .123 & -.270 & -3.598 & .000 \\
\hline
\end{tabular}

Dependent Variable: Prospect

\section{Conclusion and Recommendation \\ 5.1 Conclusion}

The study of challenging factors that affects MSEs' prospects in their continuity, profitability and job opportunity is important. For this end, the researcher examined relevant literatures, the country's development policies, Debretabor MSEs development plan and conducted sample survey by making interview with Debretabor MSEs office, Debretabor Poly Technic College and made a focused group discussion with the selected owners of MSEs and used questionnaire to base the analysis and the conclusion of the study. The respondents rated the perceived effect of 26 items on the prospects of their business. All the 26 items grouped in to five tables of Environmental, Marketing, Financial, Managerial and Control \& evaluation.

$>$ The study showed that external challenges such as intensity of competition, tax burden, small market and 
population size in the area and poor infrastructure are the challenging factors for MSEs prospects. Among which intensity of competition and poor infrastructure are the most significant factors.

$>$ The study showed that internal factors that challenge the prospects of MSEs are: marketing related problems such as lack of skill to set clear and competitive pricing policy, lack of market information and poor customer relationship and handling, and lack of demand forecasting. Control and evaluation related problems such as lack of quality control system, fear of failure of bankruptcy and risk taking, lack of inventory were investigated as influential challenging factors. Lastly financial problems such as lack of record keeping and documentation, poor management of current assets (like inventory, A/R), high investment in fixed assets during start up time, unplanned withdrawal of cash for personal use and shortage of working capital have a negative effect on the prospects of MSEs in Debretabor town.

$>$ Result of the study regarding prospects of MSEs shows that with these limitations they will sustain, but the government expects from this sector not only their sustainability, rather it is expected from this sector to facilitate economic growth and bringing about equitable development, create long term jobs, strengthen cooperation between MSEs, provide the bases for the medium and large scale enterprise and promote export. But they face constraints to reach their full potential for economic development by creating employment and providing desirable sustainability and innovation in the economy as a whole.

$>$ Regarding government policy, even though the government issued the national micro and small enterprises strategy in 1997, established the Federal Micro and Small Enterprises Development Agency and issued Ethiopia's industrial development strategy in 2003, this research investigated that the sector is still affected by the above external and internal challenges. This shows that the government has limitations to work more on practical radical approach in addition to draft the strategy.

\subsection{Recommendations}

The researcher attempted to find out factors that challenges the prospects of MSEs in Debretabor town and found out that external challenges and internal challenges such as marketing problems, financial problems, lack of control and evaluation and are the significant determinants of the prospects of MSEs in Debretabor town.

Having identified these challenging factors on the prospects of MSEs in Debretabor town, based on the results, the researcher classified his recommendations that the government and its agencies responsible for and MSEs owners themselves may accept and can be easily solved by them without the help of government. The researcher's recommendations to the external and internal challenges are as follows;

$>$ Since external challenges are beyond the control of the sector and they adversely affect the business if not eliminated, the government should take remedial actions on the challenges identified in this research. MSEs office of the town should undertake detailed study on the site to be given, should improve infrastructures like electric power and give appropriate size and location premises especially for garages, repairing service enterprises and wood workshops, encourage MSEs by lower taxes specially during their initial stages, and the local government should encourage and improve the situation to MSEs owners to operate in different sectors to minimize the intensity of competition among themselves.

$>$ Since internal challenges can be eliminated by the owner of the enterprise, owners should responsible to take the following remedial actions. To solve the problem of finance, the government should develop specially loan system/strategy for MSEs with minimum collateral amount at fair interest rate. Owners of MSEs should also create a means of solving financial problems by forming informal financial sources association like "Equib" and through savings and should avoid unplanned withdrawal of cash for personal use and should apply principles of business entity concept. MSEs should create an effort to compete with large companies by forming unions, Enterprises should make periodic inventory regularly and should work for long term loyalty with their customers rather than emphasis on short term profitability

$>$ Appropriate strategy to support the MSEs has a significant role for achievement of their objectives and this gives hope, confidence and optimism that going forward and makes attractive the SME sub-sector, but government should take practical radical approach beyond drafting the strategy and focus on important sectors and realistically should address the identified challenges.

\section{Bibliography}

Abdullah M.A and Baker M (2000), Small and Medium Enterprises in Asian Pacific Countries (Eds), Science Publishers Inc., Huntington, New York.

Ageba, G. and W. Ameha (2004), "Micro and small enterprises development in Ethiopia: Survey report"

Ethiopian Development research Institute, Research Report II

Amhara ReMSEDA Industrial extension service (2011)

Andy Field (2005) Discovering statistics using SPSS, Second Edition

Basil Anthony \&Ngwu Onugu, (2005) Small and Medium Enterprises (MSEs) in Nigeria: Problems and prospects 
Carter and Auken (2006)" Small Firm Bankruptcy" Journal of Small Business Management

CEFE International (1998) Manual for trainees

Chu M. et al., (2008) An empirical study of Nigerian entrepreneurs: success, motivations, problems, and stress.

Chuthamas Chittithaworn, Aminul Islam, Thiyada Keawchana and Dayang Hasliza Muhd Yusuf, (2011) Factors Affecting Business Success of Small \& Medium Enterprises MSEs) in Thailand

Doug Bruce and Derek Picard(2006) "Making Succession a Success: Perspectives from Canadian Small and Medium-Sized Enterprises”, Journal of Small Business Management 2006 44(2), pp. 306-309

Emerta Asaminew \& Zuzana Brixiova, (2010) SME Start Ups in Ethiopia: Which Incentives Matter?

EndalkachewMulugeta, (2008) Underlying Causes of Micro and SmallBusiness Failures Enterprises (MSEs) in Addis Ababa(The Case of Arada Sub City)

Gartner, William B. and SubodhBhat (2000) "Environmental and Ownership.Characteristics of Small Businesses and Their Impact on Development

George Manu, Robert Nelson, John Thiongo and Klaus Haftendorn. (2008) How do I become an Entrepreneur?

HabtamuTezera (undated) Challenges and Opportunities of Small and Medium Scale in Addis Ketema Sub City Survey report" Ethiopian Development Research Institute, Research Report II,

Hailay Gebretinsae (2007) Entrepreneurship and small business management. Second Edition.

Hillary R. (2000) Introduction to Small and Medium-Sized Enterprises and the environment, Sheffield: Green leaf Publishing Limited.http://www.aau.edu.et/index.php/research-andpublications

Kca Journal of Business Management: vol. $\quad 2, \quad$ issue 1 (2009).http://muse.jhu.edu/journals/eas/summary/v022/22.1ageba.html

Keith Psaila (2007) Constraints and Opportunities for Micro-enterprises in Malta

Koigi, A. N. (2011).Improving organizational effectiveness of public enterprise in Kenya.(phd) Dissertation, Nelson Mandela Metropolitan University, $308 \quad$ pp).Retrieved may 27, 2013 fromhttp://dspace.nmmu.ac.za:8080/jspui/

Konjit Debela, (undated) women in the development of Micro and Small Enterprises To Insure sustainable development

foodsecurity. .http://Portoalegrecongress2011.metropolis.org/sites/default/files/ponencies/women_konjit_de bela.pd

M. Amin, (2005). Social scince research, coneeption, Methodology and Analysis. Uganda, Kampala: Makerere unversity prente.

M. Krishna Moorthy, etal (2012). Factors Affecting the Performance of MSEs in Malaysia. International Journal of Academic Research in Business and Social Sciences April 2012, Vol. 2, No. 4 ISSN: 2222-6990

Madhurima Lall and Shirkha Sahai (2006) Entrepreneurship. New Delhi: Anurag Jain for Excel Books.

Mathew Philip (Dr.) (2010) Factors affecting business success of small \& medium enterprises volume 1, issue 2 (november, 2010) issn 2229-4104

Micro Enterprises Development Strategy of Ethiopia (published 2011)

Ministry of Trade and Industry (1997) Micro and Small Enterprises Strategy. National Micro \&Small Enterprises Agency (2005)

Mohammed Alkali, Prof Dr Abu Hassan M d Isa, and Hafiz Baba (n.d) A conceptual model of factors affecting business performance among the manufacturing sub-sector of small business enterprises in Nigeria (Bauchi state).

Mulu Gebreeyesu (2007) Growth of Micro-Enterprises: Empirical evidence from Ethiopia

Mulu Gebreeyesus (2009) Innovation and Microenterprises Growth in Ethiopia

Omobolanle OkikiSanni (2009) Problems of Establishing Small Business Enterprise In Nigeria

Osotimehin, K.O. et al (2012) An Evaluation of the Challenges and Prospects of Micro and SmallScaleEnterprisesDevelopmentinNigeria

Philip McGovern (2006) "Learning Networks as an Aid to Developing Strategic Capability among Small andMedium-Sized Enterprises: A Case Study from the Irish Polymer Industry",Journal of Small Business Management 2006 44(3), pp. 426-440

Promoting Entrepreneur ship and Innovative MSEs in a Global Economy: Towards a more reasonable and Inclusive Globalization. Istanbul, Turkey 3-5 June 2004http://www.oecd.org

RajibLahiri (undated) Problems and Prospects of Micro, Small and Medium enterprises (MSMES) in India in the era of globalization.

Robichaud, Y., McGraw, E., \& Roger, A. (2001) The development of a measurement instrument for entrepreneurial motivation. Journal of Developmental Entrepreneurship, 6, 189-202.

ShafeekSha (Undated) An Investigation into Problems Facing Small-to-Medium sized Enterprises in Achieving growth in the Eastern Cape: http://eprints.ru.ac.za/288/1/Sha- TR06-146.pdf

Stuart Locke (2006) "Information and Communication TechnologyAdoption and Small and Medium-Sized Enterprise Growth in New-Zealand”, Journal of Small Business Management 2006 44(2), pp. 298-301 
WaleligneMamo\&WendimuTerefe (2002) A servey on Idenltification of problems faced by MSEs in ANRS Welsh, M. (1988). The Corporate Enigma. Wellington: GP Books.

Yolande E. Chan, NirajBhargava, and Christopher T. Street (2006) "Having Arrived: The Homogeneity of HighGrowth Small Firms", Journal of Small Business Management 2006 44(3), pp. 426-440 